\title{
The Caddoan Occupation of the Attoyac and Angelina River Basins in the Middle Caddoan Period
}

Tom Middlebrook

Heritage Research Center, Stephen F. Austin State University

Follow this and additional works at: https://scholarworks.sfasu.edu/ita

Part of the American Material Culture Commons, Archaeological Anthropology Commons, Environmental Studies Commons, Other American Studies Commons, Other Arts and Humanities Commons, Other History of Art, Architecture, and Archaeology Commons, and the United States History Commons

Tell us how this article helped you.

This Article is brought to you for free and open access by the Center for Regional Heritage Research at SFA ScholarWorks. It has been accepted for inclusion in Index of Texas Archaeology: Open Access Gray Literature from the Lone Star State by an authorized editor of SFA ScholarWorks. For more information, please contact cdsscholarworks@sfasu.edu. 


\section{The Caddoan Occupation of the Attoyac and Angelina River Basins in the Middle}

Caddoan Period

\section{Creative Commons License}

\section{(c) (1) \&}

This work is licensed under a Creative Commons Attribution-NonCommercial 4.0 International License 


\section{The Caddoan Occupation of the Attoyac and Angelina River Basins in the Middle Caddoan Period}

\section{Tom Middlebrook}

\section{Introduction}

The Angelina River basin, including the drainage of its largest tributary, the Attoyac Bayou, encompasses all of Nacogdoches County and portions of Cherokee, Rusk, Angelina, San Augustine, Shelby, and Sabine counties in deep East Texas. Archaeological studies in the region that have illuminated our understanding of Caddoan developments have been meager and spotty at best.

There is no archaeological evidence in the Angelina River basin of extensive Caddoan occupation during the Early Caddoan period (ca. A.D. 1000-1200). Jelks (1965) presented the results of the largest archaeological project conducted in the area in his dissertation dealing with the archaeology of the McGee Bend Reservoir (Lake Sam Rayburn) by reviewing 13 sites excavated between 1956 and 1962. Every site excavated was multicomponent, and included at least some Archaic dart points, Early Ceramic period sandy paste sherds, and grog-tempered Caddoan ceramics. Jelks (1965) has been the other archaeologist to propose an archaeological taxonomic unit for the Caddoan sites based on work in the basin with his formulation of the "Angelina focus." This broad unit appears to include sites that date from ca. A.D. 1200 until historic Caddoan times, and was based, in part, upon the presence of Broaddus Brushed and Pineland Punctated-Incised ceramics at the sites.

Sorting of "Angelina focus" and related sites into temporally earlier and later groups has been recently attempted (Middlebrook 1994) based upon the relative frequencies of brushed sherds, the ratio of brushed to punctated-incised sherds, and ceramic pipe morphology (i.e., long-stemmed versus elbow). A tentative expansion of this temporal classification is presented here:

$$
\begin{aligned}
& \text { Middle Caddo: } \quad \text { Washington Square (41NA49), Sawmill (41SA89), } \\
& \text { Blount (41SA123), Tyson (4ISY92); other possible } \\
& \text { sites include Print Bell (41SB36) and Sam Stripling } \\
& \text { (41NA197) (Figure 1). } \\
& \text { Late Caddo: Walter Bell (41SB50), Etoile (41NA11), Jack } \\
& \text { Walton (41SA135), 41SY41, 41SY45, Chayah } \\
& \text { (41NA44), and Wylie Price (41SA94). } \\
& \text { Historic Caddo: } \quad \text { Deshazo (41NA27), Mayhew (4INA21), Mission } \\
& \text { Dolores de los Ais (41SA25), McElroy (4ISA116), } \\
& \text { and Wylie Price (41SA94). }
\end{aligned}
$$

\section{Key Sites of the Middle Caddoan Period}

There are only four sites in the Angelina River basin that can be ascribed to the Middle Caddoan period with some certainty. The Washington Square site will be discussed by Dr. James Corbin (see Corbin, this volume), so my comments here will be largely based upon archaeological findings at the Sawmill, Blount, and Tyson sites. 


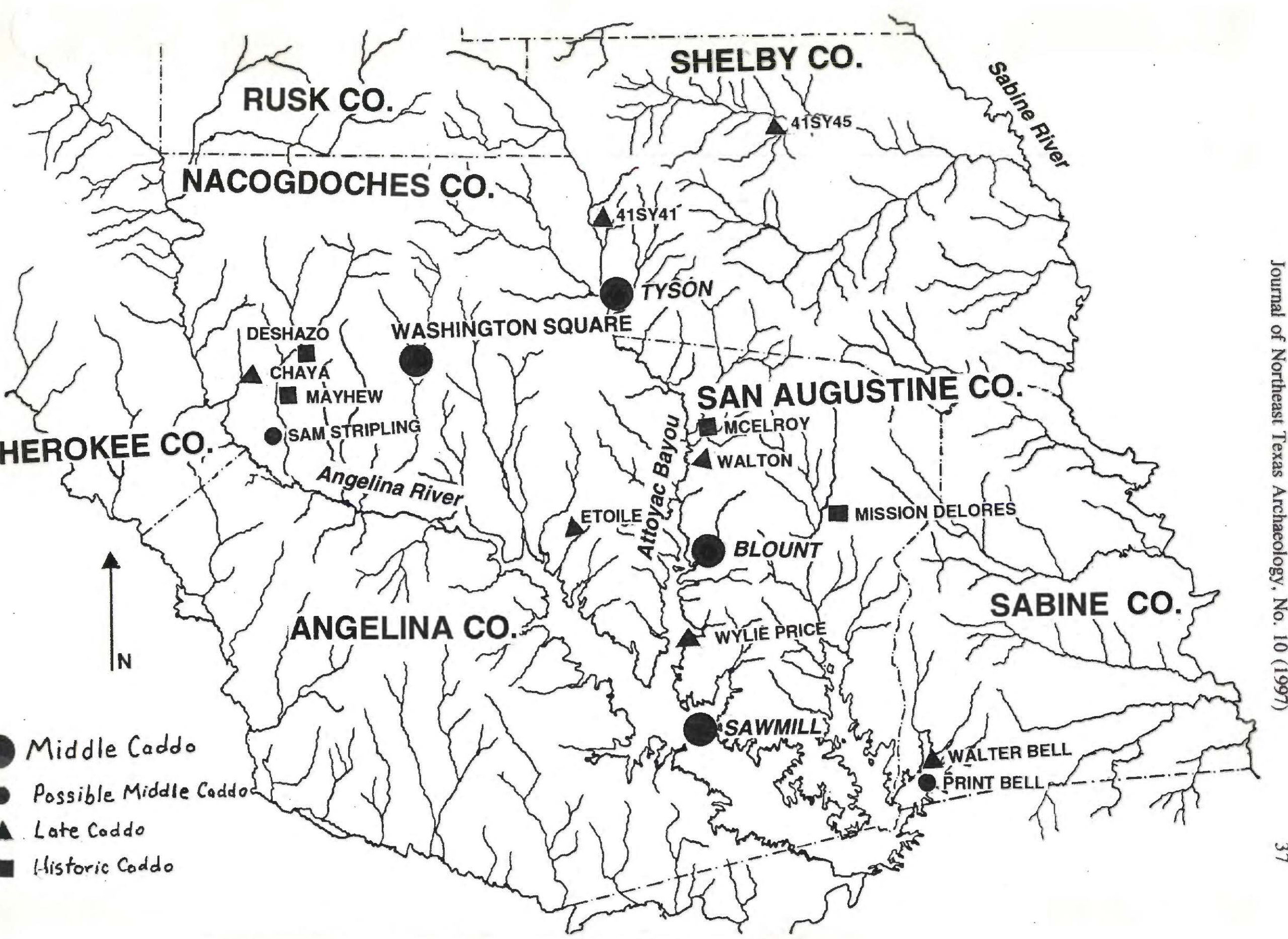

Figure 1. Middle Caddoan Sites in the Attoyac and Angelina River Basins. 
No clear settlement pattern can be discerned from these sites, but each of them appears to represent a hamlet or small village. Sawmill and Blount are situated on knolls in the floodplains of tributary streams, while Tyson is located on a prominent second terrace remnant above the confluence of Attoyac Bayou and West creek. No mound site of Middle Caddoan period age is known in deep East Texas other than Washington Square. The Tyson site, however, may have been the residence of an important local Caddoan political or religious figure (see discussion in Middlebrook 1994).

Paleobotanical analyses have not been performed for any of the sites, although samples have been retained for this purpose from the Tyson site. A wide range of aquatic, terrestrial, and avian species have been identified from the Tyson faunal materials.

A summary of key positive findings from the three Middle Caddoan period sites is presented below, including cultural features, mortuary practices, dating, and material culture.

\section{Cultural Features}

Similar cultural features reflecting domestic activities have been excavated at all three sites. While only a few postholes not forming a clear house pattern were noted at the Sawmill site, a partial outline of an oval house $5.2 \times 3.4 \mathrm{~m}$ in size was identified at the Blount site. No exterior posts have been recognized as yet at Tyson, although over 30 postholes appear to relate to a building that possibly burned (evidenced by two burned posts and daub). A probable central hearth at Tyson and an interior fireplace at Blount have been excavated (Middlebrook and Middlebrook 1996). Pits for possible storage, buming, and trash disposal have been found at each of the sites (Tyson, $n=5$; Sawmill, $n=4$; Blount, $n=1$ ).

\section{Mortuary Practices}

Two burials were excavated at the Sawmill site by the National Park Service in 1957 (Burials 1 and 2), while four more were recovered by amateurs (Burials 3-6) in 1962-1963 (Texas Archeological Research Laboratory files). The burials were not found in a cemetery, and their orientation varied widely. This information is summarized below:

Burial 1: elderly female; extended supine position, with head to the south; pronounced frontal-occipital cranial deformation; no associated artifacts.

Burial 2: middle-aged male; semi-flexed to right, with head to the northwest; associated artifacts include three Perdiz points, 14 carved shell discs and inlays near feet, one pitted stone, one ochre, and one mussel shell.

Burial 3: young adult male; extended prone position, with head to the south; marked cranial deformation; no associated artifacts.

Burial 4: elderly male; extended supine position; possible cranial deformation; associated artifacts include one small bottle in the right lumbar area, one engraved or incised bowl with concentric circle designs, two copper-covered "limestone" ear spools, one deer antler fragment, and two mussel shells.

Burial 5: adult male; legs extended supine, thorax turned to the left, and the head removed and placed on a rock "so it could look down his body;" head 
to south; associated artifacts include one small bottle left of the pelvis, and one broken and scattered bowl.

Burial 6: young adult female; semi-flexed to left, with the head to the west; associated artifacts include an engraved bird bone flute-like instrument found left of the upper body, and mussel shell.

Two infant burials were excavated at the Tyson site in 1993 (Middlebrook 1994). They appear to have been originally placed beneath a house floor:

Burial 1: two individuals approximately 18 months in age; extended supine position with the head to the west; one individual with possible cranial deformation; associated artifacts $(n=102)$ include eight ceramic vessels (including a bottle left of the head), paired deer antlers, femur, and tibia of deer, six carved shell inlays, 10 columnella beads, large marine pelecypod, a turtle carapace (rattle?), cache of six deer ulna awls and two beaver teeth, cache of 23 lithic pebble cores, preforms, flakes, and "shell points," cache of six mussel shells and three smoothed rocks, and $24+$ Olivella beads.

Burial 2: neonate; extended supine position with head to the northwest; associated artifacts include two brushed-incised ceramic vessels, two mussel shells, two columnella beads, and a large lump of potter's clay.

\section{Dating}

Six radiocarbon dates have been obtained from the three Middle Caddoan period Angelina River basin sites. Work at the Tyson site has produced four dates with good general agreement between them, and the association of the dated carbon to specific cultural activities is at least fair. The context of the samples at Sawmill and Blount is much more questionable.

Presented here are the dates from Tyson, Blount, and Sawmill. For comparison, I also include a recently obtained date from the Etoile site, thought to be of Late Caddoan age. In all cases, "charcoal" refers to woody charcoal.

\begin{tabular}{|c|c|c|c|c|}
\hline Sample No. & $\underline{\text { Site }}$ & Context & Material & One Sigma Calibrated Age \\
\hline $\mathrm{Tx}-7612$ & Tyson & F3 & Charcoal & AD 1331-1345, 1396-1438 \\
\hline $\mathrm{Tx}-7625$ & Tyson & F3 & Mussel shell & AD $1406-1438$ \\
\hline Tx-7626 & Tyson & F3 & Charcoal & AD $1414-1452$ \\
\hline Beta-97895 & Tyson & $\mathrm{B} 1$ & Mussel shell & AD $1295-1405$ \\
\hline Beta-97892 & Sawmill & N180EA & Charcoal & AD $1025-1215$ \\
\hline Beta-97893 & Blount & "distur area" & Charcoal & AD $1420-1475$ \\
\hline Beta-97894 & Etoile & "pit sample" & Charcoal & AD $1475-1655$ \\
\hline
\end{tabular}

\section{Material Culture}

The ceramic assemblages from the three sites discussed in this paper broadly overlap in character. Brushed sherds do not seem to be as common (only 10-15\%) as is the case in sites thought to be of Late Caddoan age in the Angelina River basin. Punctated-incised wares are common (punctated-incised sherds to brushed sherds ratio of $0.25-0.40$ ). There are many punctated-incised styles, and punctations in curvilinear zones are more common 
than are zones of punctation-filled triangles and diagonal lines, and far more common than with rectilinear incised lines. There is a strong predominance of Red River pipes, Haley variety, over elbow pipes.

Common vessel forms include the following: simple, globular, and carinated bowls, usually with straight/direct rims; no scalloped rims; straight-sided beaker-shaped jars are common, but also present are globular-bodied jars with everted and flaring rims. Bottles include globular, elongated, and four-comered shapes with fairly wide necks.

Engraved designs are diverse. Among the designs are negative S-shaped scrolls, circles, concentric circles, semi-circles, scrolls, circle and cross, circle with rays, ladders and ribbons filled with closely spaced parallel lines and cross-hatching, and pendant triangles; ticking is uncommon.

Red-filmed vessels and sherds are extremely rare in the Angelina River basin in the Middle Caddoan period. There are no brushed bodies associated with engraved rims, while linear impressed designs are noted, but pinched designs are very uncommon. Neck-banding is absent, and appliqued designs are very uncommon. Fingernail-impressed vessel bodies are seen, but this decorative treatment rarely occurs on rims, and never occurs in association with punctated-incised motifs.

\section{References Cited}

Jelks, E. B.

1965 The Archeology of McGee Bend Reservoir, Texas. Unpublished Ph.D. dissertation, Department of Anthropology, The University of Texas at Austin.

Middlebrook, T.

1994 An Update of Archaeological Investigations at the Tyson Site (41SY92). Journal of Northeast Texas Archaeology No. 3:1-36.

Middlebrook, T. and R. Middlebrook

1996 Of Hearths and Houses. Caddoan Archeology Newsletter 6(4):11-22. 